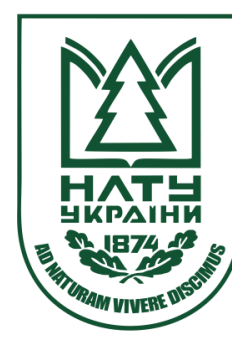

Науковий вісник НЛТУ України Scientific Bulletin of UNFU

http://nv.nltu.edu.ua

https://doi.org/10.15421/40281105

$@ \bowtie$ Correspondence author

Article received 20.12.2018 p.

Article accepted 27.12.2018 p.

U. O. Bachynska

ule156@meta.ua

удк $630 * 174.753$

У. О. Бачинська

Природний заповідник "Медобори", смт Гримайлів, Україна

\title{
ХАРАКТЕРИСТИКА ДУБОВИХ ДЕРЕВОСТАНІВ У ПРИРОДНОМУ ЗАПОВІДНИКУ "МЕДОБОРИ"
}

Встановлено, що в природному заповіднику "Медобори" насадження з участю дуба звичайного (від трьох одиниць $\mathrm{i}$ більше) є панівним типом деревостанів і займають 43,96 \% лісових площ, переважно створені штучно за типом корінних. Проаналізовано основні таксаційні показники деревостанів дуба звичайного з поквартальних підсумків Таксаційного опису природного заповідника "Медобори". Проведено віковий аналіз досліджуваних деревостанів: частка молодняків становить $9,64 \%$, середньовікових $-83,13 \%$, пристигаючих - 0,24 \%. Визначено, що деревостани з участю дуба звичайного зростають у чотирьох типах лісорослинних умов: вологій грабово-буковій діброві $(11,13 \%)$, вологій грабовій діброві $(13,65 \%)$, свіжій грабово-буковій діброві (27,85 \%), свіжій грабовій діброві (48,21 \%). За ярусністю дубові деревостани переважно $є$ простими. Встановлено, що дубняки характеризуються високою продуктивністю - 89,9 \% ростуть за першим і вище першого бонітетом. 68,6 \% насаджень - високоповнотні, а низькоповнотних $є$ вкрай мало. Математичному аналізу підлягали компоненти: вік, діаметр, повнота, запас деревостану. За розрахунковим значенням стандартного відхилення та коефіцієнта варіації можна стверджувати, що розмах варіації показника "повнота" характеризується середнім значенням мінливості ознаки. Інші показники мають широкий діапазон розсіювання у досліджених сукупностях.

Ключові слова: дуб звичайний; поквартальні підсумки; таксаційна характеристика; типи лісу.

Вступ. У лісах природного заповідника "Медобори" дуб $є$ основною лісотвірною породою, деревостани 3 його участю (у складі від трьох одиниць і більше) займають 43,96 \% від вкритої лісом площі. На території заповідника, до його заснування (1990р.), велася інтенсивна лісогосподарська діяльність, одним із пріоритетних напрямків якої було збільшення площі насаджень 3 дубом звичайним (Quercus robur L.), тому штучне його відновлення утверджувалось як домінантний напрямок відтворення дібров. На сьогодні основну частину вікового спектра популяції дуба в природному заповіднику становлять молодняки та середньовікові деревостани, переважно штучного походження (Bondarenko et al., 2006).

У наукових публікаціях стосовно природного заповідника "Медобори" наголошено про досить високий фітоценотичний потенціал дуба звичайного та рекомендовано впроваджувати систему лісівничих заходів, спрямованих на відновлення корінних природних дубових деревостанів, які зазнали істотної трансформації в ході попередньої лісогосподарської діяльності (Bondarenko, Popadynets \& Muzyka, 1998; Muzyka, 2000; Muzyka, 2003, 2004). За результатами досліджень охарактеризовано лісовий фонд заповідника, зокрема дубові лісостани (Khavyk, 1998; Holiev, 1995; Bachynska, 2017), подано характеристику природного насінного поновлення дуба в умовах заповідника (Kryshtalovych, 1998; Muzyka, 2000; Bachynska, 2013), описано видовий стан трав'яного покриву, його загальне проективне вкриття у дубово-букових насадженнях (Popadynets,
Oliiar \& Mykhailiv, 2000).

Об'єкти і методи дослідження. Для статистичного аналізу використано відомості поквартальних підсумків Таксаційного опису природного заповідника "Медобори" (Viknianske lisnytstvo, 2016; Horodnytske lisnytstvo, 2016; Krasnianske lisnytstvo, 2016), $з$ яких вибрано ділянки чистих та мішаних деревостанів дуба звичайного. Загальний обсяг вибірки становить 881 виділ загальною площею 4141,2 га. При цьому аналізували такі таксаційні характеристики досліджуваних деревостанів: площа ділянки (S), вік насадження (A), діаметр (D), висота (H), відносна повнота (P), запас на 1га (M), бонітет (B), тип лісорослинних умов та склад насадження. Для аналізу даних використовували загальні принципи математичної статистики (Rudenko, 2012) та методики, що застосовують у лісовій таксації.

Результати дослідження. Природний заповідник "Медобори" створено на вилучених 3 господарського користування землях, де лісівнича діяльність, зокрема, була спрямована на відновлення у складі лісів дуба. На сьогодні дубові ліси представлені як природними деревостанами (1106,4 га), так і насадженнями штучного походження за типом корінних (3034,8 га). Дубняки є панівним типом деревостанів і становлять 43,96 \% від лісових площ заповідника. У насадженнях з участю дуба звичайного найбільшу частку займають середньовікові деревостани, віком від 41 до 140 років, що становить $83,13 \%$, молодняки (до 40 років) - 9,64\%. Пристигаючі деревостани (віком більше 141 року) становлять

Інформація про авторів:

Бачинська Уляна Олександрівна, наук. співробітник, лісівник. Email: ule156@meta.ua

Цитування за ДСтУ: Бачинська У. О. Характеристика дубових деревостанів у природному заповіднику "Медобори". Науковий вісник НЛТУ України. 2018, т. 28, № 11. С. 29-32.

Citation APA: Bachynska, U. O. (2018). Characteristic of oak forests of Medobory Nature Reserve. Scientific Bulletin of UNFU, 28(11), 29-32. https://doi.org/10.15421/40281105 
найменшу частку - 0,24 \% від загальної площі (рис. 1).

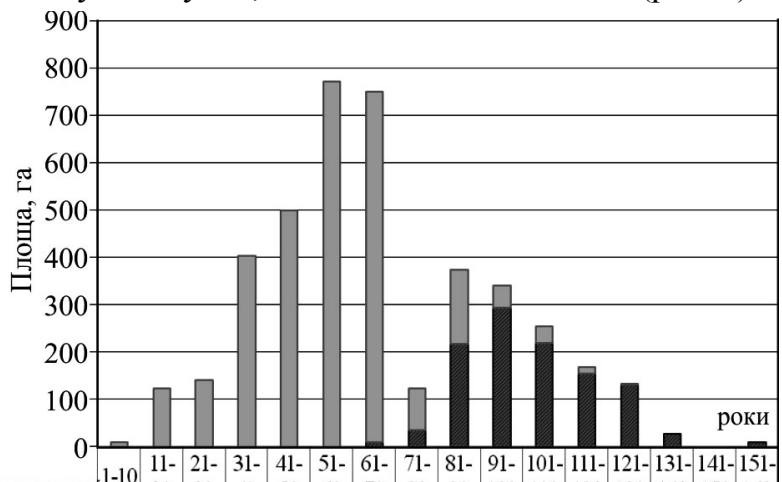

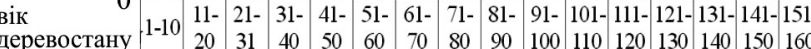
\begin{tabular}{|c|c|c|c|c|c|c|c|c|c|c|c|c|c|c|c|c|} 
деревостану $^{1-10}$ & 20 & 31 & 40 & 50 & 60 & 70 & 80 & 90 & 100 & 110 & 120 & 130 & 140 & 150 & 160 \\
\hline шाтучного i & 9,6 & 124 & 142 & 404 & 500 & 772 & 740 & 89 & 157 & 47,1 & 35,4 & 145 & 11 & 0 & 0 & 0 \\
\hline
\end{tabular} \begin{tabular}{ll|l|l|l|l|l|l|l|l|l|l|l|l|l|l|l|} 
- природного & 0 & 0 & 0 & 0 & 0 & 0,3 & 10 & 34,7 & 217 & 294 & 219 & 154 & 131 & 27,2 & 0 & 10 \\
\hline
\end{tabular} походження

Рис. 1. Розподіл площ деревостанів з участю дуба звичайного за класами віку і походженням

В умовах заповідника 99,8 \% лісів з участю дуба звичайного росте у чотирьох типах лісу: свіжій грабо- во-буковій діброві $(27,85 \%)$, свіжій грабовій діброві $(48,21 \%)$, вологій грабово-буковій діброві $(11,13 \%)$, вологій грабовій діброві (12,65\%). У свіжій грабовій судіброві, вологій грабово-буковій судіброві та сухій грабовій діброві зростає всього 0,17 \% (6,9 га). До типоутворювальної породи дуба звичайного домішуються клен гостролистий, клен явір, липа серцелиста, в'яз шорсткий. За ярусністю дубові деревостани переважно $\epsilon$ простими, здебільшого чіткого розмежування на яруси в них не виявлено. Питома частка двоярусних дубняків становить 3,4% (20 виділів площею 140,2 га).

Середній показник участі дуба в деревостанах 50,38 \%, причому насадження 3 часткою дуба 3-4 одиниці становить 45,16\% площі (рис. 2), водночас як 68,6 \% насаджень - високоповнотні (з показником відносної повноти 0,8-1,0), 31,35\% - середньоповнотні (3 показником відносної повноти $0,5-0,7)$, низькоповнотних деревостанів $є$ вкрай мало (рис. 3).

Таблиця. Статистична характеристика таксаційних показників дубових деревостанів природного заповідника "Медобори" (за відомостями поквартальних підсумків)

\begin{tabular}{|c|c|c|c|c|c|c|c|}
\hline \multirow[b]{2}{*}{ Показник } & \multicolumn{3}{|c|}{ Значення } & \multirow{2}{*}{$\begin{array}{c}\text { Стандартне } \\
\text { відхилення (б) }\end{array}$} & \multirow{2}{*}{$\begin{array}{c}\text { Коефіцієнт } \\
\text { варіації (V), \% }\end{array}$} & \multirow[b]{2}{*}{ Ексцес (Е) } & \multirow{2}{*}{$\begin{array}{l}\text { Асиметрія } \\
\text { (А) }\end{array}$} \\
\hline & Середнє Хсер ${ }^{ \pm m}$ & $\begin{array}{c}\text { Мінімальне } \\
\text { Хmin } \\
\end{array}$ & $\begin{array}{c}\text { Максимальне } \\
\text { Хmax } \\
\end{array}$ & & & & \\
\hline \multicolumn{8}{|c|}{ Д2ГБД } \\
\hline $\mathrm{A}$, роки & $66^{ \pm 1,7}$ & 13 & 126 & 25,4 & 38,6 & $-0,641$ & 0,209 \\
\hline $\mathrm{D}, \mathrm{cm}$ & $26,3^{ \pm 0,6}$ & 2 & 60 & 9,6 & 36,5 & 0,673 & 0,411 \\
\hline $\mathrm{H}, \mathrm{M}$ & $21,2^{ \pm 0,4}$ & 3 & 31 & 5,4 & 25,6 & 0,948 & $-0,844$ \\
\hline повнота & $0,77^{ \pm 0,005}$ & 0,36 & 0,98 & 0,1 & 10,6 & 2,725 & $-0,800$ \\
\hline $\mathrm{M}, \mathrm{M}^{3} /$ га & $236^{ \pm 5,9}$ & 12 & 476 & 86,9 & 36,8 & $-0,121$ & $-0,296$ \\
\hline \multicolumn{8}{|c|}{ Д2ГД } \\
\hline A, роки & $57^{ \pm 1,4}$ & 9 & 137 & 28,0 & 49,2 & $-0,067$ & 0,595 \\
\hline $\mathrm{D}, \mathrm{cm}$ & $23,7^{ \pm 0,6}$ & 2 & 64 & 12,0 & 50,9 & 0,175 & 0,557 \\
\hline $\mathrm{H}, \mathrm{m}$ & $19,2^{ \pm 0,4}$ & 0,9 & 32 & 7,2 & 37,7 & $-0,254$ & $-0,584$ \\
\hline повнота & $0,73^{ \pm 0,005}$ & 0,39 & 0,95 & 0,1 & 13,8 & 0,514 & $-0,544$ \\
\hline $\mathrm{M}, \mathrm{M}^{3} /$ га & $199^{ \pm 4,8}$ & 5 & 475 & 97,1 & 48,8 & $-0,499$ & $-0,236$ \\
\hline \multicolumn{8}{|c|}{ ДЗГБД } \\
\hline $\mathrm{A}$, роки & $75^{ \pm 3,3}$ & 13 & 161 & 33,5 & 44,7 & $-0,571$ & 0,029 \\
\hline $\mathrm{D}, \mathrm{cm}$ & $30,2^{ \pm 1,2}$ & 4 & 60 & 12,5 & 41,5 & $-0,357$ & $-0,305$ \\
\hline $\mathrm{H}, \mathrm{M}$ & $22,7^{ \pm 0,7}$ & 3,8 & 33 & 7,1 & 31,3 & 0,616 & $-1,187$ \\
\hline повнота & $0,71^{ \pm 0,001}$ & 0,32 & 0,91 & 0,1 & 14,6 & 1,690 & $-1,101$ \\
\hline $\mathrm{M}, \mathrm{M}^{3} /$ га & $246^{ \pm 10,7}$ & 17 & 727 & 110,6 & 45,0 & 2,266 & 0,220 \\
\hline \multicolumn{8}{|c|}{ ДЗГД } \\
\hline $\mathrm{A}$, роки & $60^{ \pm 2,6}$ & 11 & 127 & 30,3 & 50,6 & $-0,386$ & 0,596 \\
\hline $\mathrm{D}, \mathrm{cm}$ & $25,2^{ \pm 1,1}$ & 2 & 60 & 13,2 & 52,3 & $-0,141$ & 0,626 \\
\hline $\mathrm{H}, \mathrm{M}$ & $20,1^{ \pm 0,6}$ & 3 & 32 & 7,3 & 36,1 & $-0,351$ & $-0,548$ \\
\hline повнота & $0,71^{ \pm 0,001}$ & 0,4 & 0,97 & 0,1 & 16,3 & 0,089 & $-0,605$ \\
\hline М, м³/га & $205^{ \pm 8,6}$ & 10 & 470 & 100,0 & 48,8 & $-0,476$ & $-0,008$ \\
\hline
\end{tabular}

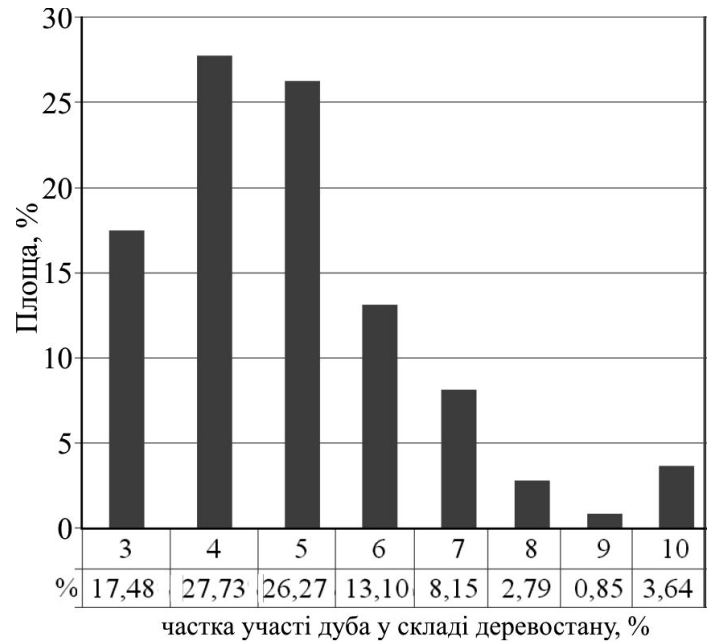

Рис. 2. Розподіл площ насаджень за часткою участі дуба звичайного у складі деревостану

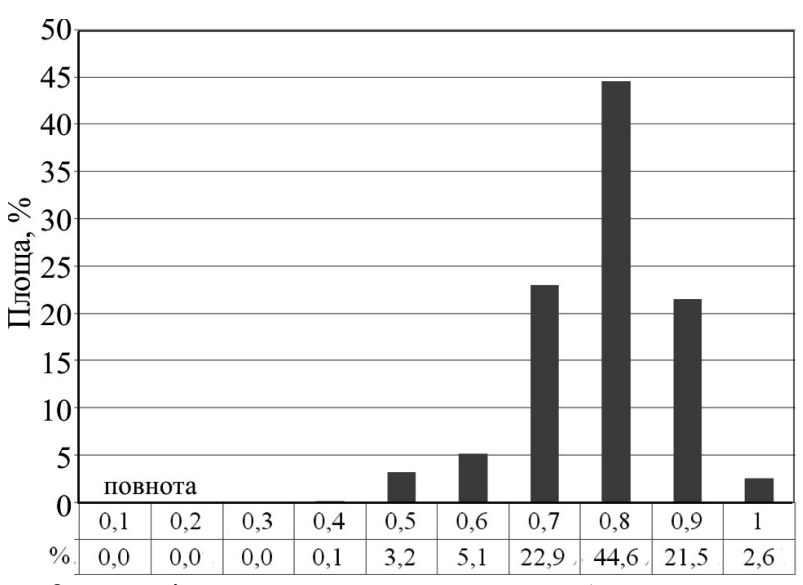

Рис. 3. Розподіл площ насаджень $з$ участю дуба звичайного за повнотою

За матеріалами лісовпорядкування (2015 р.) дубові ліси природного заповідника характеризуються висо- 
кою продуктивністю - понад 50 \% лісостанів ростуть за I класом бонітету. Понад $30 \%$ займають лісостани, клас бонітету яких вищий за I. Низькобонітетні лісостани (III та нижчих класів бонітету) займають менше 1 \% від площі вкритих лісовою рослинністю з участю дуба звичайного (рис. 4).

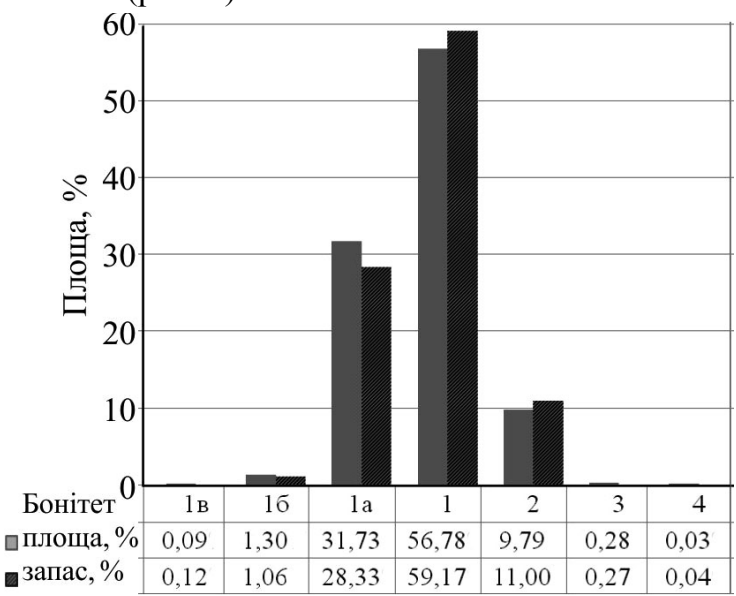

Рис. 4. Розподіл площ та запасу деревостанів з участю дуба звичайного за бонітетом

Статистичний аналіз дубових виділів за основними таксаційними параметрами наведено у таблиці. Результати оброблення свідчать про широкий діапазон розсіювання у лісотипологічних сукупностях таких таксаційних показників, як діаметр, висота та запас на одиниці площі (V - 25,6-52,3 \%), що пояснюють значною неоднорідністю вікової структури, і лише розмах варіації показника "повнота" характеризується середнім значенням мінливості ознаки (V - 10,6 -16,3\%).

Висновки. Дубові деревостани природного заповідника "Медобори" займають 43,96 \% від вкритої лісом площі. Вони переважно створені штучно за типом корінних. За групами віку переважають середньовікові насадження, а частка пристигаючих становить лише 0,24 \% від площі насаджень дуба звичайного. Дубняки ростуть переважно у свіжих і вологих грабових і грабово-букових дібровах та характеризуються високою продуктивністю - 89,9 \% з них зростає за першим і вище першого бонітетом. За ярусністю лісостани переважно є простими. 68,6 \% насаджень - високоповнотні, а низькоповнотних є вкрай мало. Дубові деревостани характеризуються значною мінливістю показників їх таксаційної будови, що є результатом впливу на них природних та антропогенних (до заповідання) чинників.

\section{Перелік використаних джерел}

Bachynska, U. O. (2013). Pryrodne ponovlennya duba zvychaynoho pid nametom materynskykh derevostaniv u pryrodnomu zapovidnyku "Medobory". Lisy, parky, tekhnolohiyi: sohodennya ta maybutnie: Tezy dopovidei uchasnykiv mizhnarodnoi naukovopraktychnoi konferentsii, (pp. 73-75). Kyiv, 360 p. [In Ukrainian].

Bachynska, U. O. (2017). Stan dubovykh derevostaniv v pryrodnomu zapovidnyku "Medobory". Naukovi zasady pryrodookhoronnoho menedzhmentu ekosystem Kanyonovoho Prydnistrovia: Materialy
Druhoyi mizhnarodnoyi naukovo-praktychnoyi konferentsiyi, (pp. 56-59). Chernivtsi: Druk Art, 320 p. [In Ukrainian].

Bondarenko, V. D., Popadynets, Y. N., \& Muzyka, M. Ya. (1998). Predydushchaya lesokhoziaistvennaia deiatelnost i problemy vosstanovleniia korennykh tipov lesa v zapovednike "Medobory". $V$ zbirnyku materialiv naukovoi konferentsii, pryurochenoi 75richchiu Krymskoho pryrodnoho zapovidnyka, (pp. 59-62). Alushta, 340 p. [In Russian].

Bondarenko, V. D., Krynytskyi, H. T., Kramarets, V. O., Muzyka, M. Ya., et al. (2006). Stratehiya i taktyka pryrodookhoronnoi diialnosti lisovoho zapovidnyka (na prykladi pryrodnoho zapovidnyka "Medobory"). Lviv: Spolom, 408 p. [In Ukrainian].

Holiev, O. M. (1995). Do kharakterystyky dubovo-bukovykh lisostaniv pryrodnoho zapovidnyka "Medobory". Problemy stanovlennia $i$ funktsionuvannia novostvorenykh zapovidnykiv: Materialy naukovo-praktychnoi konferentsii, (pp. 33-34), June 12-15. Hrymailiv, 140 p. [In Ukrainian].

Horodnytske lisnytstvo. (2016). Taksatsiinyi opys Horodnytskoho lisnytstva pryrodnoho zapovidnyka "Medobory" Ternopilskoho oblasnoho upravlinnia lisovoho ta myslyvskoho hospodarstva. Lviv, 158 p. [In Ukrainian].

Khavyk, V. P. (1998). Lisovyi fond zapovidnyka "Medobory". Medobory i dukhovna kultura davnikh, serednovichnykh slovian (do 150richchia vyiavlennia Zbrutskoho "Sviatovyda"): Materialy naukovoi konferentsii, Hrymailiv, (pp. 12-13), October 8-9. Lviv, 220 p. [In Ukrainian].

Krasnianske lisnytstvo. (2016). Taksatsiinyi opys Krasnianskoho lisnytstva pryrodnoho zapovidnyka "Medobory" Ternopilskoho oblasnoho upravlinnia lisovoho ta myslyvskoho hospodarstva. Lviv, $156 \mathrm{p}$.

Kryshtalovych, M. V. (1998). Pro kilkist ta stan samosivu duba pislia vrozhayu 1998 r. Scientific Bulletin of UNFU, 9(4), 286-105. [In Ukrainian].

Muzyka, M. Ya. (2000). Do pytannia pro zminu porid u svizhiy hrabovii dibrovi. Scientific Bulletin of UNFU, 10(4), 166-170. [In Ukrainian].

Muzyka, M. Ya. (2000). Typolohichna kharakterystyka lisiv pryrodnoho zapovidnyka "Medobory". V zbirnyku "Kontseptsiya rozvytku lisovoi typolohii $v$ Ukraini $v$ konteksti lisovoi osvity i pidvyshchennia produktyvnosti lisovykh nasadzhen": Tezy dopovidey mizhnarodnoyi naukovoyi konferentsiyi, (pp. 123-128). Kharkiv, 175 p. [In Ukrainian].

Muzyka, M. Ya. (2003). Systema lisivnychykh zakhodiv dlia vidtvorennia korinnykh pryrodnykh kompleksiv zapovidnyka "Medobory". Rol pryrodno-zapovidnykh terytorii Zakhidnoho podillia ta Yury Oitsovskoi u zberezhenni biolohichnoho ta landshaftnoho riznomanittia: Zbirnyk naukovykh prats ukrainsko-polskoi naukovoi konferentsii, (pp. 325-328). Hrymailiv-Ternopil: Lileia, 186 p. [In Ukrainian].

Muzyka, M. Ya. (2004). Korinni ta pokhidni derevostany dibrov Zakhidnoho Podillia. Scientific Bulletin of UNFU, 14(6), 138-142. [In Ukrainian].

Popadynets, I. M., Oliiar, H. I., \& Mykhailiv, O. B. (2000). Ekolohichni osoblyvosti travianoho pokryvu dubovo-bukovykh nasadzhen v umovakh pryrodnoho zapovidnyka "Medobory". Scientific Bulletin of UNFU, 10(4), 84-89. [In Ukrainian].

Rudenko, V. M. (2012). Matematychna statystyka. Kyiv: Tsentr uchbovoyi literatury, 304 p. [In Ukrainian].

Viknianske lisnytstvo. (2016). Taksatsiinyi opys Viknianskoho lisnytstva pryrodnoho zapovidnyka "Medobory" Ternopilskoho oblasnoho upravlinnia lisovoho ta myslyvskoho hospodarstva. Lviv, 176 p. [In Ukrainian].

У. А. Бачынська

Природный заповедник "Медоборы", пгт Грымайлив, Украина

\section{ХАРАКТЕРИСТИКА ДУБОВЫХ ДРЕВОСТОЕВ В ПРИРОДНОМ ЗАПОВЕДНИКЕ "МЕДОБОРЫ"}

Установлено, что в природном заповеднике "Медоборы" насаждения с участием дуба обыкновенного (от трех единиц и более) являются преобладающим типом древостоев и занимают 43,96 \% лесных площадей, преимущественно созданы искусственно по типу коренных. Проанализированы основные таксационные показатели древостоев дуба обыкновенного по 
поквартальным итогам Таксационного описания природного заповедника "Медоборы". Проведен возрастной анализ исследуемых древостоев: молодняки занимают 9,64 \%, средневековые насаждения - 83,13\%, приспевающие - 0,24 \%. Установлено, что древостои с участием дуба обыкновенного растут в четырех типах лесорастительных условий: влажной грабово-буковой дубраве $(11,13 \%)$, влажной грабовой дубраве (13,65 \%), свежей грабово-буковой дубраве $(27,85 \%)$, свежей грабовой дубраве (48,21 \%). По ярусности дубовые древостои преимущественно являются простыми. Дубняки характеризуются высокой производительностью - 89,9 \% растут по первому и выше первого бонитету. 68,6 \% насаждений - высокополнотные, а низкой полноты почти отсутствуют. Математическому анализу подлежали компоненты: возраст, диаметр, полнота, запас. По значению стандартного отклонения и коэффициента вариации можно утверждать, что размах вариации показателя "полнота" характеризуется средним значением изменчивости признака. Другие показатели имеют широкий диапазон рассеяния в исследованных совокупностях.

Ключевые слова: дуб обыкновенный; поквартальные итоги; таксационная характеристика; типы леса.

\author{
U. O. Bachynska \\ Nature Reserve "Medobory", Hrymayiliv, Ukraine
}

\title{
CHARACTERISTIC OF OAK FORESTS OF MEDOBORY NATURE RESERVE
}

Medobory Nature Reserve was created on the land abandoned for the commercial use, where forestry activities, in particular, were aimed at the restoration of oak forests. For statistical analysis, the quarterly results of the Taxation Description of Medobory Nature Reserve, which is characterized by the pure and mixed oak trees of the ordinary, were used. The total sample size is 881 units with a total area of 4141.2 hectares. In Medobory Nature Reserve, the stands of oak (usually from three or more units) are the dominant type of forest and occupy $43.96 \%$ of the forest area. Today, the oak forests are represented as natural stands (1106.4 hectares), and artificial plantings of the type of indigenous ( 3034.8 hectares). The largest share is occupied by uneven-aged stands $-83.13 \%$, young stands $-9.64 \%$, and maturing stands - only $0.24 \%$ of the total area. In the conditions of the reserve, $99.8 \%$ of oak forests grow in four forest types: fresh hornbeam-beech oak $(27.85 \%)$, wet hornbeam oak $(48.21 \%)$, wet hornbeam bilberry $(11.13 \%)$, and wet hornbeam oak (12.65\%). Concerning type-forming features, European oak, acer platanoides, sycamore maple, heart-shaped linden, and wych elm are added. According to the storey structure, oak stands are mostly simple. Reserve oak forests are characterized by their high productivity $-89.9 \%$ grow at the first and above the first yield class. $68.6 \%$ of the plantations are of high-quality, while the under-replenishment is almost absent. The components subjected to mathematical analysis were as follows: age, diameter, completeness, and stock of the tree stand. According to the estimated standard deviation and coefficient of variation, it can be stated that the scope of the variation of the "completeness" indicator is characterized by the average value of the variability of the sign. Other indicators have a wide range of scattering in forest-typological collections, which is the result of the influence of natural and anthropogenic (to the testamentary) factors.

Keywords: European oak; quarterly results; taxation characteristic; forest types. 